\title{
FUNGSI PERENCANAAN DAN PENGGERAK KEPALA SEKOLAH DALAM MENINGKATKAN MUTU PENDIDIKAN DI SD NEGERI INPRES HEDAM ABEPURA KOTA JAYAPURA
}

\author{
Agnes Aryesam \\ Faculty of Teacher Training and Education, Cenderawasih University
}

\begin{abstract}
This qualitative descriptive research has two types of data resources, namely primary data and secondary data. The primary data were the result of the interview from the data resources which determined through the purposive sampling technique. The primary data were obtained from the headmaster, teachers, administrative staff, school committees, and students. While the secondary data includes textbooks, school documents, journals, theses, dissertations, internet sites, which related to the implementation of the principal's management functions in improving the quality of education. Data were collected through in-depth interview techniques with informants, observation, and documentation. In analyzing the data, the researcher applied the qualitative descriptive techniques based on Miles and Huberman theory namely data reduction, data exposure, and data verification. There are two objectives of the research, they are 1) to describe the implementation of planning function and 2) to describe the implementation of the actuating function of the principal in improving the quality of education at Hedam Inpres State Elementary School in Abepura, Jayapura. The study revealed that 1) the principal of Hedam Inpres State Elementary School in Abepura, Jayapura has implemented the planning function properly and 2) The actuating function of the school principal had not been implemented yet.
\end{abstract}

Keywords: Principal Management Functions, Planning, Actuating, Quality of Education

\section{PENDAHULUAN}

$\begin{array}{lll}\begin{array}{r}\text { Peningkatan dan pengembangan } \\ \text { terhadap mutu pendidikan menjadi }\end{array} & \begin{array}{l}\text { dengan sebutan kontekstual. Namun tidak } \\ \text { terlepas dari tujuan pendidikan secara }\end{array} \\ \text { tanggung jawab kita semua, terutama } & \text { nasional oleh sekolah-sekolah di Papua, } \\ \text { kepala sekolah. Kepala sekolah memiliki } & \text { khususnya kota Jayapura tergantung dari } \\ \text { peran penting dalam peningkatan mutu } & \text { bagaimana pimpinan tertinggi dari sekolah } \\ \text { pendidikan di sekolahnya, yang } & \text { tersebut, yaitu kepala sekolah berani } \\ \text { disesuaikan dengan konteks setempat, } & \text { melakukan terobosan-terobosan, } \\ \text { atau dalam istilah pendidikan dikenal } & \text { memaknai sebuah kebijakan. Pada }\end{array}$


faktanya, hal tersebut belum tercermin secara keseluruhan dalam kinerja kepala sekolah.

Keberhasilan pendidikan dan pengembangan sekolah sangat ditentukan pada peran dan fungsi kepala sekolah yang berkaitan dengan kemampuan manajerial kepala sekolah.

Tugas kepala sekolah selain dalam lingkup sekolah juga harus memiliki kemampuan dalam ketatausahaan, membina hubungan sekolah dengan masyarakat, orang tua. Sebagai administrator, kepala sekolah harus mampu menjadi manajer yang memiliki kemampuan manajerial yang baik dalam hal menyusun perencanaaan kegiatan pembelajaran sekolah, menyususn struktur organisasi sekolah, menjadi koordinator dalam organisasi sekolah, mengelola kepegawaian dalam organisasi sekolah, sebagai supervisor, dan lain sebagainya.

G. R. Terry (Sagala,2011) mengemukakan teori manajemen pendidikan khususnya tentang fungsifungsi manajemen bahwa kepala sekolah harus melaksanakan tugas-tugasnya yang meliputi, (1) planning (perencanaan), 2) organizing (pengorganisasian), actuating (menggerakan), (4) controling (pengawasan) dan evaluation (penilaian). Salah satu sekolah yang tidak mengalami perkembangan dalam manajerial kepala sekolah adalah SD Negeri Inpres Hedam Abepura Kota Jayapura. Dari hasil observasi awal diperoleh informasi bahwa SD Negeri Inpres tersebut mengalami stagnan, yaitu tidak mengalami perubahan dan perkembangan mutu pendidikan dari waktu ke waktu. Kondisi seperti ini tentunya disebabkan oleh beberapa faktor yang tidak berfungsi secara maksimal, salah satu di antaranya adalah kepala sekolah belum berperan secara aktif dan kreatif dalam melaksanakan fungsi dan tanggung jawabnya. Berdasarkan data penelitian terdahulu tentang fungsi manajemen sudah pernah dilakukan, diantaranya oleh Tadius (2013) dengan judul "Peran Kepala Sekolah dalam Meningkatkan Kompetensi Guru SDN 7 Sintang”. Hasilnya peran kepala sekolah belum maksimal dalam beberapa aspek, antara lain peran supervisi dan administrator. Selanjutnya penelitian semacam ini juga pernah dilakukan oleh Lubis Maesaroh (2008) dengan judul "Keterampilan Manajerial Kepala Sekolah dalam Meningkatkan Mutu Pendidikan 
pada SMA Negeri I Perbaungan", hasil penelitiannya (a) Kepala sekolah memiliki pemahaman terhadap visi misi sekolah; (b) upaya pelaksanaan visi misi dilakukan secara bertahap;(c) Pengelolaan pendidikan bermutu didukung faktor kepemimpinan kepala sekolah (d) wujud kepemimpinan di SMA I Perbaungan berjalan baik. Merujuk pada dua penelitian terdahulu, maka dipandang perlu untuk melakukan sebuah penelitian yang dapat dipakai sebagai model untuk melaksanakan kegiatan manajerial bagi kepala sekolah di jenjang SD karena kegiatan penelitian ini belum pernah dilakukan sebelumnya.

Masalah di atas menjadi dasar pertim bangan peneliti untuk melaksanakan kegiatan pengkajian, yang berkaitan dengan implementasi fungsi-fungsi manajemen kepala sekolah khususnya pada fungsi planing dan actuating. Berdasarkan uraian masalah tersebut, dengan demikian perlunya penelitian lebih lanjut sejauh mana manajerial kepala sekolah SD Negeri Inpres telah melaksanakan peran dan fungsinya sebagai pemimpin dalam melaksanakan tugas menejerialnya dalam upaya meningkatkan mutu pendidikan disekolah yang dipim pinnya.

Fokus penelitian ini berkaitan dengan kemampuan manajerial kepala sekolah untuk meningkatkan mutu pendidikan di sekolah, khusus pada implementasi fungsi-fungsi manajemen. Adapun judul penelitian ini adalah "Implementasi Fungsi Planning dan Actuating Kepala Sekolah dalam Mening katkan Mutu Pendidikan di SD Negeri Inpres Hedam Abepura Kota Jayapura".

Tujuan penelitian adalah

mendeskripsikan implementasi fungsi planning (perencanaan) Kepala sekolah dalam meningkatkan mutu pendidikan, dan (2) mendeskripsikan implementasi fungsi actuating (menggerakkan) kepala sekolah dalam meningkatkan mutu pendidikan.

\section{METODOLOGI PENELITIAN}

Penelitian ini dilakukan di SD Negeri Inpres Hedam J1. Biak Abepura Kota Jayapura. Waktu Penelitian ini dilaksanakan selama 3 bulan mulai dari bulan Agustus 2018 hingga bulan Oktober 2018. Jenis penelitian ini adalah deskriptif kualitatif, data yang dinyatakan dalam bentuk kata-kata, kalimat, narasi, 
uraian, dan berbagai bentuk pemahaman lainnya. Bogdan (1992) mendefinisikan metode kualitatif sebagai prosedur penelitian yang menghasilkan data deskriptif berupa kata-kata atau lisan dari orang-orang dan perilaku yang diamati.

Penelitian kualitatif menurut Lexy

J. M. Oleong (2000) adalah penelitian yang secara holistik bermaksud untuk memahami fenomena tentang apa yang dialami subyek penelitian, baik perilaku, persepsi, motivasi maupun tindakannya, dan secara deskriptif dalam bentuk katakata dan bahasa, pada suatu konteks khusus yang alamiah dengan memanfaatkan berbagai metode alamiah.

Penelitian ini menggunakan metode deskriptif analitis, dan pendekatannya menggunakan pendekatan kualitatif. Alasan digunakannya metode dan pendekatan tersebut sesuai data yang diperoleh yaitu data implementasi fungsi perencanaan dan penggerak kepala sekolah di SD Negeri Inpres Hedam Abepura Kota Jayapura. Diharapkan dapat mampu menghasilkan suatu uraian mendalam tentang representasi fungsi perencanaan dan penggerak kepala sekolah SD Negeri Inpres Hedam Abepura Kota Jayapura.
Sumber data penelitian ini adalah informan yang meliputi: (1) kepala sekolah, (2) guru-guru, (3) tata usaha, (4) komite sekolah, dan (5) siswa. Sumber data ini mencakup dua bagian, yaitu sumber data utama (data primer) dan data sekunder. Sumber data primer, yaitu data yang diambil langsung atau dikumpulkan langsung dari sumber datanya, yaitu data dari hasil wawancara dari informan sebagai sumber data yang ditentukan secara purposive sampling yaitu sumber informan ditetapkan berdasarkan pertimbangan tertentu dari peneliti yang dipandang layak menjadi sumber informan. Sumber data sekunder sesuai dengan masalah penelitian, seperti (data tertulis), yaitu data yang dikumpulkan peneliti dari berbagai sumber yang telah ada (peneliti sebagai tangan kedua). Data sekunder adalah meliputi buku teks, dokumen sekolah, jurnal, disertasi, situs internet yang terkait tentang implementasi fungsi perencanaan dan penggerak kepala sekolah dalam meningkatkan mutu pendidikan.

Metode yang digunakan untuk mendapatkan data yang valid adalah dengan menggunakan empat metode yaitu observasi, wawancara, studi 
dokumentasi,dan triangulasi. Peneliti melakukan observasi dengan cara mengamati langsung ke Sekolah Dasar Negeri Inpres Hedam Abepura Kota Jayapura guna memperoleh informasi mengenai implementasi fungsi perencanaan dan penggerak kepala sekolah dalam meningkatkan mutu pendidikan.

Pengertian wawancara dijelaskan oleh Endang Danial (2009) yaitu "wawancara adalah teknik mengumpulkan data dengan cara mengadakan dialog, tanya jawab antara peneliti dan informan secara sungguh-sungguh. Dalam pelaksanaannya peneliti melakukan wawancara kepada kepala sekolah, guru, staff tata usaha, komite sekolah, dan siswa dengan menggunakan pedoman wawancara. Endang Danial (2009) menyatakan "Studi dokumentasi adalah mengumpulkan sejumlah dokumen yang diperlukan sebagai bahan data informasi sesuai dengan masalah penelitian, seperti peta, data statistik, gambar, dan sebagainya".

Instrumen dalam penelitian ini mencakup tiga instrumen, yaitu meliputi data utama adalah peneliti sendiri, selanjutnya setelah fokus penelitian menjadi jelas, maka kemungkinan akan dikembangkan instrumen penelitian sederhana, yang dapat melengkapi data dan membandingkan dengan data yang telah ditemukan melalui Lembar observasi, pedoman wawancara, dan dokumentasi.

Nasution (1996) mengemukakan bahwa tahapan analisis data adalah sebagai berikut, tidak ada suatu cara tertentu yang dapat dijadikan pendirian bagi semua penelitian, salah satu cara yang dapat dianjurkan adalah mengikuti langkah-langkah yaitu reduksi data, display data dan penarikan kesimpulan /verifikasi.

Hasil penelitian yang direduksi merupakan data yang diperoleh melalui observasi, wawancara,studi dokumentasi,dan studi literatur. Display data adalah data hasil penelitian yang sudah tersusun secara terperinci untuk memberikan gambaran penelitian secara utuh. Data yang terkumpul secara terperinci dan menyeluruh selanjutnya dicari pola hubungannya untuk dijadikan simpulan sementara. Kesimpulan awal yang ditemukan masih bersifat sementara dan akan berubah bila tidak ditemukan bukti-bukti yang kuat yang mendukung 
pada tahap pengumpulan data berikutnya. Kesimpulan dalam penelitian kualitatif adalah merupakan temuan baru yang sebelumnya belum pernah ada.

Dalam penelitian ini untuk menguji keabsaan data, penulis hanya menggunakan satu dari 5 jenis alat uji keabsahan data, yaitu dengan menggunakan uji kredibilitas. Sugiyono (2009) menyatakan cara yang dapat dilakukan untuk mengusahakan agar kebenaran hasil penelitian dapat dipercaya, yaitu perpanjangan pengamatan, mening katkan ketekunan, diskusi teman sejawat, triangulasi, dan member chek.

\section{HASIL DAN PEMBAHASAN}

Fungsi kepala sekolah sebagai perencana (planning) sudah terlaksana dengan baik, namun pada fungsi penggerak kepala sekolah belum mengimplementasikan secara maksimal., karena guru sebagai aset yang sangat berharga di sekolah, semestinya dapat bekerja sama dengan kepala sekolah dalam melaksanakan semua programprogram yang telah direncanakan akan tetapi pada kenyataannya tidak demikian. Guru hanya diberi kewenangan sebatas tugasnya sebagai pengajar, yaitu menyiapkan perangkat pembelajaran, mengajar, dan melaksanakan ujian. Sementara program tahunan yang lain tidak dilibatkan oleh kepala sekolah.

Menggerakan (Actuating) menurut Terry (1977) berarti merangsang anggota -anggota kelompok melaksanakan tugastugas dengan antusias dan kemauan yang baik.Tugas menggerakan itu harus dilaku kan oleh pemimpin. Oleh karena itu kepemimpinan kepala sekolah mempunyai peranan yang sangat penting dalam menggerakkan personal sekolah dalam melaksanakan kerjanya.

Faktor-faktor yang mendukung implementasi fungsi perencanaan dan penggerak kepala sekolah adalah adanya kerja sama yang baik antara sekolah, komite, dan dinas pendidikan, sarana prasarana yang cukup memadai,sedangkan faktor peng hambatnya adalah kurangnya tenaga guru, tidak adanya tenaga administrasi (staf tata usaha), tidak adanya pembagian tugas yang jelas, serta kurangnya komunikasi antara kepala sekolah dan guru.

Dampak dari kepala sekolah belum mengimplementasikan fungsi penggerak dengan baik dan benar, a) status 
akreditasi, b) prestasi akademik maupun non akademik, c) Nilai Ujian Sekolah (US), dan Nilai Ujian Nasional (UAN) dari tahun ke tahun selama tiga tahun terakhir tidak mengalami peningkatan, sedangkan proses belajar mengajar, pembagian tugas guru mengalami hal yang sama. Dari hasil wawancara diperoleh data bahwa sistem komunikasi tidak berjalan antara kepala sekolah dengan komponen belajar yang lain menyebabkan terjadinya hambatan implementasi.

\section{SIMPULAN DAN SARAN}

\section{A. SIMPULAN}

1. Kepala SD Negeri Inpres Hedam Abepura telah mengimplementasikan fungsi peren- canaan dengan baik.

2. Fungsi penggerak kepala sekolah di SD Negeri Inpres Hedam Abepura belum diimplementasikan, karena guru sebagai aset yang sangat berharga di sekolah semestinya dapat bekerja sama dengan kepala sekolah dalam melaksanakan peningkatan mutu pendidikan di SD Negeri Inpres Hedam di Kota Jayapura.

\section{SARAN}

1. Kepala sekolah harus lebih meningkatkan kemampuan manajerial, melakukan supervisi, dan mengoptimalkan komunikasi kepada guru.

2. Hendaknya bekerja sama dengan sesama guru dan kepala sekolah untuk meningkatkan mutu pendidikan.

3. Dinas Pendidikan Kota Jayapura agar pro aktif dalam membantu kepala sekolah, guru dalam menigkatkan kwalitas pendidikan di kota Jayapura.

\section{DAFTAR PUSTAKA}

Bogdan, RC., and Biklen, S.K., 1992. Qualitative Reseacrh for Education. Boston: Allyn and Bacon.

Danial, E. 2009. Metode Penulisan Karya Ilmiah.Bandung:Laboratorium Pendidikan Kewarganegaraan.

Handoko. 2002. Manajemen. Yogyakarta: BPFE.

Maesaroh,Lubis.2008.Ketrerampilan Manajerial Kepala Sekolah dalam Meningkatkan Mutu Pendidikan (Studi Kasus Pada SMA Negeri I Purbaungan). Tesis. S2 Manajemen 
Pendidikan,Universitas

Cenderawasih.

Minarti, Sri, 2011. Mmanajemen Sekolah

Mengelola lembaga pendidikan secara

mandiri, Depok Sleman Jokjakarta.

M. Oleong Lexy J.2000. Metodologi Penelitian

Kualitatif.Bandung:PT.Remaja

Rosdakarya.

Nasution, S. 1996. Meode Penelitian Naturalistik Kualitatif. Bandung: Tarsito.

Sagala Syaiful, 2011. Manajemen Strategik dalam Meningkatan Mutu Pendidikan. Alvabeta CV Bandung.

Sugiyono. 2009. Statistika Untuk Penelitian. Bandung: Alfabeta.

Tadius. 2013. Peran Kepala Sekolah dalam Meningkatkan Kompetensi Guru SDN 7 Sintang. Jurnal Pendidikan Universitas Tanjungpura Pontianak. Vol 15, No. 1: 1-16. 